\title{
Tworząc skrawek historii... Wybrane inicjatywy z zakresu popularyzacji zasobu Archiwum Nauki PAN i PAU w 2019 r.
}

\begin{abstract}
„Zbiorowa pamięć każdej wspólnoty, stanowiąca fundament jej tożsamości, jest jakąś wypadkową utrwalonych i rozpoznanych pamięci indywidualnych, jednostkowych. Pamięć jednostkowa natomiast - nie ta mglista, właściwa dla tradycji ustnej, ale ukonkretniona i dająca się udokumentować - ma swoje oparcie w spuściznach jednostek, żyje na swój sposób w ich osobistych archiwach"1.

Idąc o krok dalej w interpretacji powyższego cytatu, można by dodać, że pamięć o archiwach osobistych i ich twórcach żyje głównie dzięki inicjatywom podejmowanym przez instytucje, w których są przechowywane. Bogactwo i różnorodność spuścizn to temat trudny do wyczerpania czy zamknięcia w sztywnych ramach ${ }^{2}$. Materiały pozostające po uczonych nie tylko zasługują na zainteresowanie, ale i wręcz ,domagają się" pokazania publiczności. Szeroko rozumiana popularyzacja sprzyja zaś budowaniu świadomości historycznej, wpływa na odbiór społeczny archiwum czy efektywność podejmowanych przez nie działań ${ }^{3}$.
\end{abstract}

W 2019 r. Archiwum Nauki Polskiej Akademii Nauk i Polskiej Akademii Umiejętności (dalej: Archiwum Nauki) podjęło szereg inicjatyw dotyczących promocji swojego zasobu. Podobnie jak w latach ubiegłych odbyły się wernisaże wystaw oraz kontynuowano projekty badawcze w ramach współpracy krajowej i zagranicznej. Rozbudowano ofertę edukacyjną, adresowaną nie tylko do uczelni, ale również szkół średnich. Zorganizowano konferencję naukową integrującą środowisko specjalistów, a także warsztaty dla studentów i archiwistów zakładowych. Każde z podjętych przedsięwzięć zasługuje na szczegółowe omówienie, a niniejszy tekst będzie zaledwie ich skróconą prezentacją.

Najważniejszym wydarzeniem ubiegłego roku była kolejna już konferencja metodyczna „Spuścizna w XXI wieku - problemy gromadzenia, opracowywania i udostępniania”

${ }^{1}$ Jerzy Wyrozumski, Słowo wstępne, [w:] Małgorzata Mrówka, Marcin Maciuk, Ocalone od niepamięci... Co kryja archiwa osobiste uczonych $i$ twórców? W 10. rocznicę powolania Archiwum Nauki PAN i PAU w Krakowie, Kraków 2012, s. 5.

${ }^{2}$ Zob. szerzej: Rita Majkowska, Bogactwo, różnorodność, rozproszenie... Archiwum osobiste (spuścizna) okiem archiwisty, [w:] Spuścizny - co po nas zostaje? Zagadnienia metodologiczne, red. Adam Górski, Kraków 2018, s. 11-16; eadem, Archiwum osobiste czy spuścizna? Z tradycji gromadzenia materiałów pochodzenia prywatnego w Krakowie w XIX $i$ XX wieku, [w:] VI Konferencja Archiwów Instytucji Naukowych w Polsce. Kraków 13-14 IX 2001 r., red. Jerzy Michalewicz, Z prac Archiwum UJ, Seria F Varia t. 3, Kraków 2002, s. 11-21.

${ }^{3}$ Zob. szerzej: Marlena Jabłońska, Komunikacja społeczna i public relations $w$ archiwach. Zarys problematyki badawczej, [w:] Archiwa-Kancelarie-Zbiory, t. 2, red. Waldemar Chorążyczewski, Robert Degen, Krzysztof Syta, Torun 2008, s. 63-80. 
(16 października 2019 r. $)^{4}$, objęta patronatem honorowym przez Naczelnego Dyrektora Archiwów Państwowych. Wzięli w niej udział przedstawiciele: Archiwum Narodowego w Krakowie, Polskiej Akademii Nauk (dalej: PAN) Archiwum w Warszawie, Uniwersytetu Warszawskiego, Biblioteki Kórnickiej, Instytutu Masaryka i Archiwum Akademii Nauk Republiki Czeskiej, Instytutu Historii Uniwersytetu Karola i Archiwum Uniwersytetu Karola w Pradze oraz archiwów państwowych.

Konferencja była poświęcona archiwom osobistym w różnych ośrodkach naukowych i archiwalnych. W syntetyczny sposób podsumowała problemy, z jakimi borykają się instytucje gromadzące tego typu materiały. Wysoka frekwencja oraz ożywione obrady pokazały, jak ważna była to inicjatywa, tym bardziej że w środowisku archiwistów coraz mocniej podkreśla się zaniechanie dysputy nad metodyką opracowywania zasobu archiwalnego. Coraz więcej uwagi poświęca się za to dokumentowi elektronicznemu w związku z systemem Elektronicznego Zarządzania Dokumentacją (EZD) ${ }^{5}$. Nieprzypadkowo zagadnienie to zdominowało dyskusję towarzyszącą posiedzeniu.

Nowe technologie, nośniki informacji, bazy danych oparte na tych samych hasłach kluczowych to bez wątpienia najważniejsze wyzwania współczesnych archiwów. Znalazły one również odzwierciedlenie w tematyce wygłoszonych referatów ${ }^{6}$. Nie można jednak zapominać, że metodyka opracowywania zasobu to niezwykle obszerna i wielowątkowa problematyka badawcza, a postępująca standaryzacja opisu nie może oznaczać jej marginalizacji ${ }^{7}$. Szczególnie mocno wybrzmiewa jednak dzisiaj pytanie o efekty. Rewizja dotychczasowego dorobku to nie próba negacji fundamentów polskiej archiwistyki, ale szukania rozwiązań lepszych, wydajniejszych, przyszłościowych. Tym bardziej że w ostatnich latach można było zaobserwować rozwój ,,paradygmatu dostępu do archiwaliów”8. Z drugiej strony, zbliżenie archiwów do potrzeb użytkowników, digitalizacja przyjmująca postać

\footnotetext{
${ }^{4} \mathrm{Na}$ temat wcześniejszych konferencji zob. Bernadeta Wilk, Konferencje naukowe Archiwum Nauki PAN i PAU w Krakowie w latach 2007-2013, „Krakowski Rocznik Archiwalny” 2014, t. 20, s. $157-164$.

${ }^{5}$ Zob. Irena Mamczak-Gadkowska, Krzysztof Stryjkowski, Wstęp, [w:] Metodyka i standardy opracowania archiwalnego. Rzeczywistość i potrzeby, red. Irena Mamczak-Gadkowska, Krzysztof Stryjkowski, Poznań 2019, s. 7.

${ }^{6}$ Szczegółowy program zob.: Spuścizna w XXI wieku - problemy gromadzenia, opracowywania i udostęniania. Program konferencji naukowej Archiwum Nauki PAN i PAU, 16 października 2019 r., http://archiwumnauki.pan.pl/?p=1655 (odczyt: 29.01.2020).

${ }^{7}$ Zob. np. Wiesława Kwiatkowska, Opracowanie archiwalne w Polsce w dobie standaryzacji opisu archiwalnego. Zmiana metodyki czy narzędzi pracy?, [w:] Metodyka i standardy..., s. 11-19; Waldemar Chorążyczewski, Ewolucja standardów opisu archiwalnego, [w:] Problemy archiwalnego opisu informacyjnego, red. Waldemar Chorążyczewski, Agnieszka Rosa, Symposia Archivistica t. 4, Warszawa 2017, s. 13-21; Bohdan Ryszewski, Metodyka opisu archiwalnego $w$ polskich systemach informatycznych, [w:] Problemy archiwalnego opisu..., s. 23-29; Paweł Perzyna, Standaryzacja opisu archiwalnego a digitalizacja, [w:] Standaryzacja opisu archiwalnego, red. Jerzy Bednarek, Paweł Perzyna, Symposia Archivistica t. 3, Warszawa 2016, s. 17-41.

${ }^{8}$ Zob. szerzej: Angelika Menne-Haritz, Dostęp do archiwów, czyli przeformułowanie archiwalnego paradygmatu, „Archeion” 2002, t. 104, s. 68-95. Tekst pierwotnie zamieszczony w „Archival Science" 2001, Vol. 1, s. 57-82.
} 
wieloletnich projektów nie mogą sprowadzać ich funkcji do „fabryki informacji”. Coraz ważniejszą rolę w procesie zabezpieczania dokumentacji odgrywają też archiwa naukowe, w tym skupione na spuściznach. Nie powinny one wycofywać się z płaszczyzny badawczej i archiwoznawczej. Podjęte przez prelegentów zagadnienia, takie jak: rozproszenie, kwestie prawne związane z pozyskiwaniem, gromadzeniem oraz udostępnianiem tego typu materiałów, pozostają bowiem aktualne i z pewnością będą powracać podczas posiedzeń inicjowanych w różnych ośrodkach naukowych.

Wychodząc naprzeciw oczekiwaniom związanym z powyższymi aspektami, wydarzenie dało asumpt do podjęcia w niedalekiej przyszłości kompleksowej dyskusji z udziałem archiwistów praktyków nad Wytycznymi opracowywania spuścizn archiwalnych po uczonych ${ }^{9}$. Tym samym poruszona problematyka zaowocowała planami zorganizowania kolejnych konferencji oraz warsztatów specjalistycznych. Mamy nadzieję, że spotkania te wpiszą się w kanon dobrych praktyk i przyniosą oczekiwane rezultaty.

Odzew społeczny, z jakim spotkały się obrady, pokazuje, jak ważnym elementem promocji archiwum jest jego działalność naukowa. Niemniej jednak, głównym narzędziem popularyzacji zasobu pozostają wystawy, cieszące się od lat niesłabnącym zainteresowaniem $^{10}$. Rok 2019 przyniósł wyjątkowe okazje, które stały się impulsem do przygotowania kolejnych ekspozycji, tym razem na podstawie materiałów ze spuścizn geologów. Pierwsza z nich to 75. rocznica bitwy o Monte Cassino oraz 60. rocznica polskiej wyprawy na Spitsbergen, kolejne - 130. rocznica urodzin Walerego Goetla i 100-lecie założenia obecnej Akademii Górniczo-Hutniczej im. Stanisława Staszica w Krakowie (dalej: AGH).

Tłumy zgromadził wernisaż ekspozycji „Zostawić po sobie ślad. Wojciech Narębski żołnierz i uczony" (6 czerwca - 5 września 2019 r. $)^{11}$, poświęconej profesorowi geochemii, sybirakowi, żołnierzowi 2. Korpusu Polskiego, uczestnikowi bitwy o Monte Cassino. W uroczystości, oprócz tytułowego bohatera, wzięli udział m.in. przedstawiciele Polskiej Akademii Umiejętności (dalej: PAU), Urzędu ds. Kombatantów i Osób Represjonowanych Małopolskiego Urzędu Wojewódzkiego, Instytutu Nauk Geologicznych Uniwersytetu Jagiellońskiego (dalej: UJ), Centrum Edukacji Przyrodniczej UJ, Instytutu Kultury Włoskiej, Towarzystwa Przyjaciół Wilna i Ziemi Wileńskiej, Archiwum Narodowego, Centrum Ope-

${ }^{9}$ Wytyczne opracowania spuścizn archiwalnych po uczonych, oprac. Hanna Dymnicka-Wołoszyńska, Zygmunt Kolankowski, przy udziale Stanisława Chankowskiego, Jana A. Igielskiego, Józefa Mizikowskiego, Elżbiety Sztraj, Warszawa 1990.

${ }^{10} \mathrm{Na}$ temat wystaw z lat 1994-2014 zob. np. Rita Majkowska, Archiwum w stużbie nauki... Działalność ekspozycyjna i jej znaczenie, [w:] Amico, socio et viro docto. Księga ku czci profesora Andrzeja Kazimierza Banacha, red. Tomasz Pudłocki, Krzysztof Stopka, Kraków 2015, s. 185-197; nt. wystaw z 2015 r. zob. Marcin Maciuk, Małgorzata Mrówka, Wokót 200. rocznicy powołania Towarzystwa Naukowego Krakowskiego (1815-1872), „Krakowski Rocznik Archiwalny" 2016, t. 22, s. 240-242; nt. wystaw z lat 2016-2018 zob. Paulina Krzywda, W trosce o zachowanie pamięci... Działalność popularyzatorska Archiwum Nauki PAN i PAU w latach 2016-2018, „Krakowski Rocznik Archiwalny” 2018, t. 24, s. 334-342.

${ }^{11}$ Wystawie towarzyszyła publikacja: Zostawić po sobie ślad. Wojciech Narębski-żotnierz i uczony. 75. rocznica bitwy pod Monte Cassino, autorzy tekstów: Tomasz Filip, Marzena Włodek, Kraków 2019. 
racji Lądowych-Dowództwa Komponentu Lądowego oraz harcerze z Niezależnego Związku Harcerstwa „Czerwony Mak” ze Skawiny.

Podczas otwarcia nie brakowało atrakcji. Członkowie Grupy Rekonstrukcji Historycznej „Karpaty” chętnie opowiadali o umundurowaniu, tradycji czy dziejach 2. Korpusu. Chór Schola Cantorum Cracoviensis, którego prof. W. Narębski przez wiele lat był członkiem, zaśpiewał pieśni „Czerwone maki na Monte Cassino” oraz „Modlitwę obozową”. I choć dziś słowa brzmią inaczej, a czas zatarł ich pierwotne znaczenie, to jednak podniosła atmosfera skierowała myśli zebranych w stronę wydarzeń sprzed 75 lat. Symboliczny bukiet czerwonych maków postawiony w sali wystawowej podkreślał poświęcenie tych, których droga „z ziemi włoskiej do Polski” nagle się urwała, a jej kres zwieńczyły białe krzyże, jak w ostatnich słowach pieśni Feliksa Konarskiego: Bo wolność krzyżami się mierzy. Historia ten jeden ma błąd. Kwiaty powędrowały również do rąk Gościa Honorowego, który dokłada wszelkich starań, by pamięć o bohaterach spoczywających na obcej ziemi nie została pogrzebana wraz z nimi. Część oficjalną spotkania zamknął hejnał mariacki, przypominając o tym, że w zdobytym klasztorze na Monte Cassino nie tylko załopotały biel i czerwień, ale ponad złomami ruin i skał rozniosły się znajome dźwięki jako znak polskiego zwycięstwa.

Celem wystawy było zaprezentowanie dorobku oraz działalności W. Narębskiego jako żołnierza, naukowca i społecznika ${ }^{12}$. Niewielka przestrzeń ekspozycji pozwoliła zaledwie na zarysowanie pewnych wątków czy etapów niezwykłego życia uczonego na tle losów rodziny i skomplikowanych warunków politycznych. Motywem przewodnim stały się jego własne słowa: „Moją maksymą życiową jest Zostawić po sobie ślad. Chodzi mi o to, by moje życie miało sens, abym coś mądrego i wartościowego po sobie zostawił"13. Trzeba podkreślić, że spuścizna złożona w Archiwum Nauki pełna jest owych śladów ${ }^{14}$. Pozostanie nieocenionym źródłem dla badaczy choćby z zakresu historii nauki. Niemniej jednak, wkład Profesora włożony w wychowanie kolejnych pokoleń w duchu patriotyzmu już rodzi owoce, a jego osoba przyciąga młodych, potrzebujących autorytetów. Wchodzą w życie pozbawieni dziejowego bagażu, ale nie oznacza to, że nie chcą być świadomi swojej historii.

Warto nadmienić, że powyższa refleksja oraz trwająca już lata przyjaźń Archiwum Nauki z prof. Narębskim skłoniły instytucję do objęcia patronatem honorowym projektu „Meldunek filmowy Kaprala Wojtka”, zrealizowanego przez Stowarzyszenie Polonistów w ramach programu „Patriotyzm Jutra” Muzeum Historii Polski w Warszawie. Towarzyszy mu popularyzacja dziecięcej inicjatywy rekomendowania Profesora do Kapituły Orderu Uśmiechu ${ }^{15}$.

Wystawę otwierały reprodukcje z widokami Wilna. Sentymentalny portret miasta przykuwał uwagę wybranymi miejscami jak np. dom W. Narębskiego w Zaułku Montwiłłow-

${ }^{12}$ Więcej na temat życiorysu: Wojciech Narębski, Andrzej Kobos, Zostawić po sobie ślad..., [w:] Po drogach uczonych. Z członkami Polskiej Akademii Umiejętności rozmawia Andrzej M. Kobos, t. 3, red. Wanda Lohman, Kraków 2008, s. 515-537.

${ }^{13}$ Ibidem, s. 536.

${ }^{14}$ Archiwum Nauki, Wojciech Narębski, sygn. K III-261.

${ }_{15}$ Meldunek filmowy Kaprala Wojtka, http://www.stowarzyszeniepolonistow.pl/meldunekkaprala-wojtka/ (odczyt: 18.01.2020). 
skim. Zdjęcia w kolorze sepii wprowadzały w atmosferę świata, który minął bezpowrotnie. Kącik rodzinny z fotografiami bliskich przypominał o tej najważniejszej w życiu wartości oraz latach szkolnych, naznaczonych harcerstwem. Działalność konspiracyjną w Związku Wolnych Polaków przypłacił aresztowaniem w wieku 16 lat (1941 r.), osadzeniem na Łukiszkach, wywiezieniem do miasta Gorkij, następnie sowchozu Darowskoje. Z więzienia został uwolniony po układzie Sikorski-Majski. Prezentowane eksponaty przypominały o piekle sowieckiej zsyłki i rozpoczętej wędrówce. Wyprowadzony przez Andersa z „nieludzkiej ziemi” stał się żołnierzem ,,armii zwycięstwa”. A droga była daleka. Szlak nadziei wiódł przez trzy kontynenty. Po utworzeniu Polskich Sił Zbrojnych trafił jako kierowca ciężarówki do 2. Korpusu, z którym brał udział w kampanii włoskiej. Służył tutaj słynny niedźwiedź Wojtek. Na wystawie nie mogło zabraknąć również tego akcentu. „Duży Wojtek" był nie tylko przyjacielem żołnierzy, ale i symbolem 22. Kompanii Zaopatrywania Artylerii. Z uwagi na wspomnianą już rocznicę najwięcej miejsca poświęcono właśnie wątkowi walki o Półwysep Apeniński, zilustrowanemu specjalnym fotoreportażem pt. „Od Sangro do Bolonii - kadry z kampanii włoskiej”.

Druga część ekspozycji prezentowała udział W. Narębskiego w wyprawie polarnej na Spitsbergen (3 czerwca - 4 września 1959 r.), drogę do zawodu, osiągnięcia oraz karierę naukową. Aktywną postawę społeczną obrazowały wątki działalności w Towarzystwie Przyjaźni Polsko-Włoskiej czy Towarzystwie Miłośników Wilna i Ziemi Wileńskiej. Eksponowane w imponującej liczbie medale, adresy jubileuszowe, dyplomy, a także wyróżnienia podkreślały szacunek, jakim cieszy się nie tylko na ziemi polskiej, by wymienić przykładowo: Italy Star, brytyjskie odznaczenie wojskowe za udział w działaniach bojowych na terenie Włoch podczas II wojny światowej (10 stycznia 1946 r.); Krzyż Oficerski Orderu Zasługi Republiki Włoskiej (28 kwietnia 2005 r.) czy rzadko przyznawany Rycerski Order św. Sebastiana, nadany przez królewską rodzinę Portugalii za pielęgnowanie wartości patriotycznych i propagowanie historii (18 kwietnia 2017 r.). Nie sposób nie wyliczyć również Medalu „Pro Patria” za szczególne zasługi w kultywowaniu pamięci o walce o niepodległość (12 lipca 2012 r.), a i tak będzie to tylko skromny wybór.

Wystawa „Zostawić po sobie ślad...” stanowiła świadectwo niezwykłej drogi życiowej, otwartej postawy oraz niezależności myśli jednego człowieka. Czas usuwa ze zbiorowej pamięci ludzi i zdarzenia. Wciąż jednak żyją świadkowie walczący o idee, fakty warte utrwalenia czy uhonorowania. Wychowawczy dialog pokoleń nie opiera się na suchych datach zapisanych w szkolnych podręcznikach, a działalność popularyzatorska archiwów musi uwzględniać również aspekt edukacyjny. Jedna z osób zwiedzających ekspozycję napisała w księdze pamiątkowej Archiwum Nauki słowa, które wydają się najlepszą recenzją wydarzenia: „Składam ogromne podziękowania twórcom tej przestrzeni. Zapewne nigdy nie miałbym możliwości poznania człowieka, którego życie przetoczyło się przez ruiny Monte Cassino, brytyjską ziemię, PRL i wolną Polskę. Tacy ludzie, zwykli, popularni, sza$r z y$ pokazują, jakie jest prawdziwe życie. A to życie buduje każdy z nas, tworząc skrawek historii".

Kolejna wystawa „Walery Goetel (1889-1972). Urodziłem się jako jeden z tych, którzy maja ciekawość świata... W 130. rocznicę urodzin Walerego Goetla i 100-lecie powstania Akademii Górniczo-Hutniczej w Krakowie” (16 października - 29 listopada 2019 r.) po- 
święcona była Waleremu Goetlowi ${ }^{16}$, rektorowi AGH, twórcy nowej dyscypliny naukowej - sozologii. Jego licząca ok. 25 mb spuścizna złożona w Archiwum Nauki ${ }^{17}$ wielokrotnie dostarczała już materiałów do różnych wystaw tematycznych ${ }^{18}$. Nic więc dziwnego, że 130. rocznica urodzin uczonego stała się inspiracją, by wreszcie uczcić bezpośrednio tego, który mimo upływu lat, pozostał konsekwentnie wierny swoim pasjom, przekuwając je w rodzaj powołania zawodowego. Wspomnienia, którymi podzielili się podczas wernisażu wnuczka i wnuk profesora - Jadwiga i Piotr Chrząstowscy - ukazały również bardzo osobisty rys niezwykłego człowieka. Jego miłość do Tatr przypomniał występ kapeli góralskiej. Żywiołowa muzyka podkreśliła także charakter badacza, którego całe życie upłynęło „Pod znakiem optymizmu"19. Konspekt wspomnień profesora pod takim właśnie tytułem posłużył organizatorom za podstawę, na której oparto kompozycję wystawy.

Ekspozycja tym samym stanowiła rodzaj biograficznego szkicu, prowadzącego zwiedzających przez całe życie uczonego. Pozorna prostota w układzie pozwoliła na uzyskanie jasnego wywodu. Opowieść płynnie wiodła po czasach, ludziach, zdarzeniach. Otwierały ją dzieciństwo i młodość będące wstępem do późniejszej zorganizowanej działalności zawodowej, społecznej czy politycznej. O tym najwcześniejszym etapie pełnym fascynacji sportem, turystyką przypominały eksponaty, jak choćby narty, bądź materiały ukazujące jego działalność w Akademickim Klubie Sportowym, który współtworzył począwszy od 1908 r. Atmosfera Krakowa początku XX w. sprzyjała natomiast nawiązywaniu licznych kontaktów na niwie kulturalnej i nie tylko. Przyjaźń z Rafałem Malczewskim, pobyt w pałacu Lanckorońskich w Wiedniu, ślub z Marią Skłodowską, bratanicą polskiej noblistki - to tylko niektóre z poruszonych aspektów.

Prezentowane dokumenty, korespondencja czy przedmioty codziennego użytku wprowadzały kolejne wątki, odsłaniając stopniowo obraz człowieka zaangażowanego w tworzenie pogranicznych parków narodowych, odbudowę, a następnie rozbudowę AGH, wreszcie biorącego również udział w kolejnych zjazdach czy kongresach naukowych. Za swe wyjątkowe zasługi w dziedzinie ochrony przyrody i jej zasobów otrzymał w 1959 r. najwyższe w tym zakresie odznaczenie międzynarodowe: nagrodę i medal. im. van Tienhovena, eksponowany w jednej z gablot. Subiektywny wybór archiwaliów pozwolił organizatorom zaledwie na zaakcentowanie tego, co najważniejsze we wszechstronnej działalności W. Goetla, będąc jednocześnie zachętą do bliższego zapoznania się z jego zajmującym życiorysem.

${ }^{16}$ Więcej na temat życiorysu: Zbigniew Wójcik, Walery Goetel. Rektor trudnych czasów Akademii Górniczo-Hutniczej, Kraków 2009; Stefan Witold Alexandrowicz, Walery Goetel (18891972), „Rocznik Polskiego Towarzystwa Geologicznego” 1973, t. 43, z. 4, s. 555-568.

${ }^{17}$ Archiwum Nauki, Walery Goetel (1889-1972), sygn. K III-36.

${ }^{18}$ Ich pokłosiem są publikacje oraz okolicznościowe foldery, by wymienić przykładowo: Marcin Maciuk, Joanna Laskosz, By wzniesś się ponad szczyty... Z kontaktów uczonych polskich, czeskich i slowackich w XX w., Kraków 2013; Marcin Maciuk, Ocean wszechrzeczy... w spuściznach ludzi nauki i kultury, Kraków 2014 (współpraca Maria Urgacz); Joanna Laskosz, Marzena Włodek, Nauka ponad granicami. Z zagranicznych kontaktów uczonych polskich $w$ XX w., Kraków 2016; Ewa Dziurzyńska, Polscy uczeni $w$ świecie. Wymiana inspiracji $i$ wiedzy $w$ kontaktach uczonych Europy Środkowej, Kraków 2017.

${ }^{19}$ Walery Goetel, Pod znakiem optymizmu, Kraków 1976. 
Prawdziwą ucztę wizualną stanowiły wybrane fotografie z podróży do Gruzji (1912 r.), na Islandię (1927 r.) czy do Afryki (1929 r.), pokazujące tytułową ciekawość w oczach uczonego, który zawsze pozostawał otwarty na świat i ludzi. Trzeba przyznać, że w pozostawionych relacjach, wspomnieniach uderza jego zmysł obserwacji oraz gawędziarski talent. Wędrówkę śladami W. Goetla ułatwiało zwiedzającym kalendarium systematyzujące podstawowe wiadomości z jego życia. Ekspozycji towarzyszyła okolicznościowa publikacja, ilustrowana materiałami ze spuścizny geologa, z tekstami: Joanny Laskosz, Zbigniewa Wójcika, Andrzeja Paulo oraz Piotra Chrząstowskiego ${ }^{20}$. Rozpoczyna ona nową serię wydawniczą Człowiek i Uczony. Warto nadmienić, że w dniu wernisażu odbyła się również promocja książki prof. Z. Wójcika, wpisującej się w główne wątki działalności tytułowego bohatera $^{21}$.

Zainteresowanie, z jakim spotkała się wystawa, pokazuje wyraźnie, że w dobie digitalizacji, coraz większej aktywności w przestrzeni wirtualnej, tradycyjne ekspozycje nadal zajmują istotne miejsce, a użytkownicy chcą mieć możliwość bezpośredniego obcowania ze źródłem. Wychodząc naprzeciw oczekiwaniom społecznym, w listopadzie 2019 r. zorganizowano dla uczniów szkół średnich z Suchej Beskidzkiej oraz I Liceum im. Bartłomieja Nowodworskiego w Krakowie oprowadzanie kuratorskie połączone z zajęciami historyczno-archiwalnymi. Uczestnicy mogli zapoznać się z różnymi typami źródeł, technikami fotograficznymi czy spróbować swoich sił w zakresie odczytania XIX-wiecznego tekstu. Przedstawiono również rolę i zadania archiwum, specyfikę pracy archiwisty, a przede wszystkim zaprezentowano unikatowe materiały wytworzone przez uczonych reprezentujących różne dyscypliny nauki. Celem tego typu zajęć jest promocja polskich badaczy, ich dokonań, wkładu w rozwój badań, a także uzmysłowienie młodzieży, że nauka nie jest tylko ciągiem abstrakcyjnych dat, faktów i zjawisk, ale ma też „twarz” konkretnego człowieka.

Archiwum Nauki nie tylko kontynuuje tradycję organizowania rocznie dwóch ekspozycji poświęconych uczonym, których materiały gromadzi, ale i przygotowuje wystawy posterowe czy planszowe. Jedna z nich - „Dzieje nauki i historia ludzi - zasób Archiwum Nauki PAN i PAU" - towarzyszyła X Warszawskiemu Piknikowi Archiwalnemu (8 czerwca 2019 r.). Instytucja wzięła w nim udział po raz pierwszy, promując swój zasób oraz działalność. Zwiedzający zapoznali się z ofertą wydawniczą, a pracownicy odpowiedzieli na wiele pytań. Spotkania tego typu sprzyjają skróceniu dystansu między archiwami a użytkownikami oraz nawiązaniu nowych kontaktów.

Inny charakter miały wystawy zorganizowane we współpracy z krakowskimi instytucjami. Nauka ustąpiła w nich miejsca sztuce, udowadniając jednocześnie po raz kolejny, że te dwie wartości podążają w parze. Wspólnie z Galerią Ekslibrisu w Krakowie zorganizowano wystawę: „Czesław Woś. Grafika, ekslibris” (5-30 kwietnia 2019 r.). Pokłosiem współpracy z Biblioteką Naukową PAU i PAN w Krakowie były ekspozycje: „Ewa Zawadzka. Grafika i rysunek z kolekcji Gabinetu Rycin Biblioteki Naukowej PAU i PAN"

${ }^{20}$ Walery Goetel (1889-1972). Urodziłem się jako jeden z tych, którzy maja ciekawość świata... W 130. rocznice urodzin prof. Walerego Goetla oraz 100-lecie powstania Akademii Górniczo-Hutniczej im. Stanisława Staszica w Krakowie, oprac. Joanna Laskosz, Człowiek i Uczony t. 1, red. Adam Górski, Kraków 2019.

${ }^{21}$ Zbigniew Wójcik, Walery Goetel (1889-1972). By w góry byto po co chodzić. O turystyce, parkach, narodowych $i$ sozologii, Kraków 2019. 
(11 września - 4 października 2019 r.) oraz „Ex musicis - ekslibrisy muzyczne ze zbiorów Biblioteki Naukowej PAU i PAN w Krakowie" (11 grudnia 2019 r. - 23 stycznia 2020 r.). Wernisażowi tej ostatniej towarzyszył recital fortepianowy utworów Stanisława Moniuszki, podkreślający obchody 200. rocznicy urodzin kompozytora. Ze zbiorów Archiwum Nauki zaprezentowano archiwalia ze spuścizn: Władysława Kotwicza (1872-1944), Kazimierza Nitscha (1874-1958), Kazimierza Miczyńskiego (1868-1918) oraz materiały Komisji Etnograficznej z zespołu akt PAU. Całości dopełniały druki muzyczne z Biblioteki Rozdolskiej Lanckorońskich przechowywanej na ul. św. Jana 26. Wspomnianym wyżej ekspozycjom towarzyszyły bogato ilustrowane wydawnictwa ${ }^{22}$.

W działalności popularyzatorskiej archiwum ważną rolę odgrywają pokazy, które w minionym roku spotkały się z ogromnym zainteresowaniem. Wśród uczestników znaleźli się członkowie Stowarzyszenia Archiwistów Polskich, archiwiści zakładowi instytutów PAN w Krakowie czy studenci. Spotkania miały na celu zapoznanie z miejscem, zasobem, zasadami opracowywania, a przede wszystkim różnorodnym światem spuścizn. Znaleźć w nich przecież można nie tylko materiały naukowe uczonych, ale również liczne ślady ich różnych pasji - młodzieńcze rysunki, szkice, karykatury, akwarele, fotografie z podróży, notatki. Wzrok przykuwają prezentowane odznaczenia i dyplomy. Analiza tego typu źródeł pozwala obserwować, jak dojrzewała postać przyszłego profesora; jak nieśmiałe pierwsze zapiski torowały mu stopniowo drogę na karty historii nauki, a wszystko dzięki wytrwałej pracy.

Wyjątkową prezentację dokumentów ze spuścizny Władysława Kotwicza (1872-1944) przygotowano w dniu 30 września 2019 r. Archiwalne mury odwiedził wówczas J.E. pan Nemekh Bataa, ambasador nadzwyczajny i pełnomocny Mongolii w Rzeczypospolitej Polskiej. Pokazy uatrakcyjniły również dwie edycje warsztatów dla studentów UJ, prowadzone w ramach kursu „Digitalizacja i udostępnianie archiwów publicznych” (24 czerwca oraz 14 grudnia 2019 r.), a także warsztaty z zakresu gromadzenia i przekazywania materiałów archiwalnych dla archiwistów zakładowych instytutów PAN (29 października 2019 r.).

Zwracając uwagę na aspekt edukacyjny swojej działalności, Archiwum Nauki wystąpiło w roli współorganizatora konkursu naukowo-kulturowego „Plus ratio quam vis... Służąc Ojczyźnie - pracą, myślą, talentem”, zainicjowanego przez Akademię Żakowską, Stowarzyszenie Szersze Horyzonty oraz Muzeum UJ Collegium Maius. Jego celem jest propagowanie miejsc związanych ze środowiskiem naukowo-artystycznym Krakowa oraz dorobku uczonych i twórców kultury. W dniach 6-7 maja 2019 r. w siedzibie Archiwum odbyły się warsztaty dla uczestników. Hasłem przewodnim prowadzonych zajęć była szeroko rozumiana „ciekawość świata” - inspirująca badaczy, zachęcająca do podróży czy poszerzania horyzontów.

Popularyzacja nauki oraz wiedzy to działalność sięgająca korzeniami XIX w. W przeciągu stuleci jej formy ewoluowały, ulegając znacznym zmianom wymuszonym zarówno

${ }^{22}$ Czesław Woś. Grafika i ekslibris, [oprac.] Jacek Owczarek, Kraków 2019; Ewa Zawadzka. Grafika i rysunek z kolekcji Gabinetu Rycin Biblioteki Naukowej PAU i PAN w Krakowie, oprac. Jan Motyka, Kraków 2019; Agnieszka Fluda-Krokos, Ex musicis. Ekslibrisy muzyczne ze zbiorów Biblioteki Naukowej PAU i PAN w Krakowie. Katalog wystawy, Kraków 2019. 
czynnikami politycznymi, jak i kulturowo-społecznymi ${ }^{23}$. Obecnie nie może pozostawać w oderwaniu od nowoczesnych źródeł informacji czy mediów społecznościowych pozwalających na alternatywne formy edukacji ${ }^{24}$. Dla Archiwum Nauki aktywność w przestrzeni wirtualnej to też sposób na podtrzymywanie pamięci o twórcach spuścizn, ukazywania swojej roli w społeczeństwie oraz rozwijania świadomości historycznej. Stąd też istotnymi narzędziami pozostają strona internetowa (uruchomiona w nowej odsłonie) oraz facebook. W 2019 r. zamieszczono 254 posty. Profil służy eksponowaniu ciekawszych obiektów, prezentowaniu sylwetek uczonych (okazją są zazwyczaj rocznice ich urodzin, śmierci), a także promocji bieżących wydarzeń z życia instytucji.

Mówiąc o informatyzacji w archiwach, najczęściej sięga się do tematu oferowanych przez nie baz danych i elektronicznych repozytoriów. Zachęcamy do odwiedzenia bazy danych „Spuścizna”, ukazującej integralność zespołów osobistych wbrew masowemu zjawisku rozproszenia, czy skorzystania $\mathrm{z}$ fotografii zamieszczonych na platformie projektu „PAUart. Katalog zbiorów artystycznych i naukowych Polskiej Akademii Umiejętności”. Z dokumentami zespołu akt Towarzystwa Naukowego Krakowskiego użytkownicy mogą zapoznać się pod adresem: inwentarz.tnk.krakow.pl. Prowadzone w roku minionym prace pozwoliły na udostępnienie na stronie kolejnych blisko 12 tys. skanów - to prawdziwy skarbiec i niewyczerpana kopalnia wiedzy dla naukowców niemal wszystkich dyscyplin, historyków nauki, regionalistów oraz miłośników Krakowa.

W dzisiejszych czasach to archiwiści muszą stawać się ambasadorami pamięci o polskich uczonych. Współpraca krajowa i zagraniczna pozwala na nawiązywanie nowych kontaktów, przekładających się na promocję zbiorów. W roku ubiegłym, współdziałano na zasadzie partnerstwa z AGH - w związku z obchodami 100-lecia jej założenia, przekazano kopie fotografii ze wspomnianej już spuścizny W. Goetla. Utrzymano porozumienie z Wydziałem Filozoficznym UJ, któremu udostępniono materiały ze spuścizny Romana Ingardena (1893-1970) na potrzeby realizowanego tam projektu „Cyfrowe Archiwum Romana Ingardena. Spuścizna epistolarna Romana Ingardena jako świadectwo rozwoju polskiej filozofii i jej związków ze światową humanistyką w XX wieku”. Z uwagi na obchody Roku Rembrandta użyczono obiekt na wystawę zorganizowaną przez Zamek Królewski w Warszawie, pt. „36 x Rembrandt” (4 października - 3 listopada 2019 r.). Współdziałano również z Instytutem Masaryka i Archiwum Akademii Nauk Republiki Czeskiej w ramach projektu ,Jak naukowcy budowali swoje sieci? Rekonstrukcja kontaktów naukowych i stosunków transnarodowych między czeskimi i polskimi uczonymi w XIX i XX wieku". Z kolei spuścizna Władysława Kotwicza, na której opiera się współpraca Archiwum z Zakładem Turkologii i Ludów Azji Środkowej Wydziału Orientalistyki Uniwersytetu Warszawskiego oraz Instytutem Historii i Archeologii Mongolskiej Akademii Nauk, stała

${ }^{23}$ Zob. szerzej: Kamila Siuda, Czynniki kulturowo-społeczne warunkujące formy działalności popularyzatorskiej w polskich archiwach XX i na początku XXI wieku, [w:] Popularyzacja nauk historycznych - teoria i praktyka. Zbiór studiów, red. Dominika Gołaszewska-Rusinowska, Małgorzata Mielewska, Tomasz Sińczak, Toruń 2018, s. 63-73, https://repozytorium.umk. pl/handle/item/5430/Popularyzacja Nauk Historycznych.pdf?sequence=2 (odczyt: 18.01.2020).

${ }^{24}$ Zob. szerzej: Monika Cołbecka, Oferta archiwów w Internecie w zakresie kształcenia użytkowników, [w:] Popularyzacja nauk historycznych..., s. 75-90. 
się tematem kolejnych rozmów prowadzonych w Seulu oraz Ułan Bator, otwierających zarazem perspektywy nowych przedsięwzięć badawczych.

Inicjatywy podjęte przez Archiwum Nauki w 2019 r. będą kontynuowane oraz rozwijane w kolejnych latach. Dzięki nim spuścizny „żyją”, a pamięć o ich twórcach jest kultywowana. Każdy zespół pochodzenia prywatnego jest inny i wymaga odrębnego traktowania. Te wszystkie ślady tworzą jednak skrawek historii składający się na naszą tożsamość. Tym samym wszelkiej działalności z zakresu popularyzacji (zwłaszcza ekspozycyjnej) nie można traktować jako tylko alternatywnej formy udostępniania źródeł poza pracownią naukową. Nie można z niej też rezygnować ani jej ograniczać, gdyż poprzez jej szerokie spektrum ujawnia się ich fenomen: ,[...] bogactwo, niezwykłość, różnorodność, a przede wszystkim unikatowość - bo tak jak niepowtarzalne jest życie człowieka, tak unikatowe są spuścizny" 25 .

Paulina Krzywda Archiwum Nauki PAN i PAU w Krakowie

${ }^{25}$ R. Majkowska, Bogactwo, różnorodność, rozproszenie..., s. 16. 
